\title{
Forest ecosystem monitoring in Tuscany (Italy): past activities, present status and future perspectives
}

\author{
Luigi BARTOLOZZI, Ilaria BONINI ${ }^{1)}$, Renzo BORETTI, Filippo BUSSOTTI ${ }^{2)}$, Enrico CENNI $^{3)}$, \\ Alessandro CHIARUCCI ${ }^{1)}$, Alberto COZZI ${ }^{3)}$, Vincenzo DE DOMINICIS ${ }^{1)}$, Marco FERRETTI ${ }^{3)}$, Paolo GROSSONI ${ }^{2)}$, \\ Gianluca LANDI, Claudio LEONZIO' ${ }^{1)}$ and Giovanni VIGNOZZI
}

\author{
Regione Toscana, Dip. Sviluppo Economico, Servizio Foreste e Patrimonio Agroforestale. Via di Novoli 26, 50127 Firenze, Italy \\ ${ }^{1)}$ Dipartimento di Scienze Ambientali, Via P.A. Mattioli 4, 53100 Siena, Italy \\ ${ }^{2)}$ Dipartimento di Biologia Vegetale, Piazzale delle Cascine 28, 50144 Firenze, Italy \\ ${ }^{3)}$ Linnaea-Ambiente, Via G. Sirtori 37, 50137 Firenze, Italy \\ *e-mail corresponding author: filippo.bussotti@unifi.it
}

\begin{abstract}
Since 1987 the Region of Tuscany has been actively monitoring crown status in its forests, in order to protect them from atmospheric pollution, biotic factors and environmental change. Over this period the Region has performed periodical inventories on crown condition in publicly-owned forests (Level I network) and established a network of permanent plots (MON.I.TO., Level II III) to study long-term changes occurring in forest ecosystems. Some of these permanent plots were later included in the national programme CONECOFOR, managed by the Ministry for Policy in Agriculture and Forest. Currently a further development of MON.I.TO. is being implemented, called MONITO III - TOpModel, the aim of which is to broaden the information potential of the monitoring system to include carbon stocks and biodiversity evaluation. This paper provides an up-to-date report on the status of the various surveys and recommends a closer connection between MON.I.TO. and the other regional information systems, especially the Regional Forest Inventory, in order to produce information that may be useful in forest planning and in Sustainable Forest Management.
\end{abstract}

Key words: integrated monitoring, forest condition, air pollution, carbon stock, biodiversity

\section{INTRODUCTION}

Forest coverage in Tuscany exceeds one million hectares, of which 120,000 belong to the "Regione Toscana" as public property, administered by local authorities (Comunità Montane and Municipalities), and another 100,000 to other public institutions. In Tuscany, forests have always been a resource of fundamental importance; they remain to be fully developed in economic and productive terms, but are also seen as an increasingly valuable asset for the environment and for the landscape. The active relation between man and nature has been decisive in the creation of different environments, of forest landscapes and structures, each unique and unrepeatable. The development of the rural landscape in Tuscany is also connected to the correct appreciation of woods as a resource, of their societal and cultural meaning, and not just their productive significance. The memory and conservation of cultural forestpractices from the past could become a valid cultural stimulus and attraction for naturalistic tourism. The forest sector today is called upon to respond to demands that are much more diversified than in the past, reflecting the needs of a constantly changing society. Forest areas increasingly serve the needs of a general interest which goes far beyond the interests of private property: as a carbon sink, as a green space where people can spend their leisure time, as an environment favouring soil conservation and a place where water can be stored and protected. These new needs require a gradual adaptation of our overall forest culture, as well as specific forest management practices and continuous surveillance. In particular, the biological cycles of the principal forest species, which are normally very long, require the adoption of long-term planning as a rule and method for forest management.

In this context, the crown condition of the forests belonging to the Region of Tuscany has been monitored since 1987, with the aim of defending forests against atmospheric pollution, parasite infestations and environmental factors in general. Tuscany was one of the first regions in Italy to establish this kind of monitoring programme, which was co-funded by the European Union within the "Scheme for the protection of forests against atmospheric pollution" (EU Regulation 3528/86 and following). Originally the monitoring network was extensive (the so-called Level I network, see below), in other words aiming at providing statistics on the status of trees in public forests. At a later stage, alongside the Level I network, another network was set up, intensive in nature (Level II and III), called MON.I.TO. (MONitoraggio Intensivo delle foreste TOscane, Intensive Monitoring of Forests in Tuscany), whose purpose was to provide information on other structural and functional aspects of Tuscany's forest ecosystems. The third stage of this development saw MON.I.TO. moving beyond the

Paper prepared within the CONECOFOR programme, by the contract with the Ministry for Agriculture and Forestry Policy - National Forest Service, Italy. CONECOFOR is part of the Pan-European Level II Intensive Monitoring of Forest Ecosystem and is co-sponsored by the European Commission. 


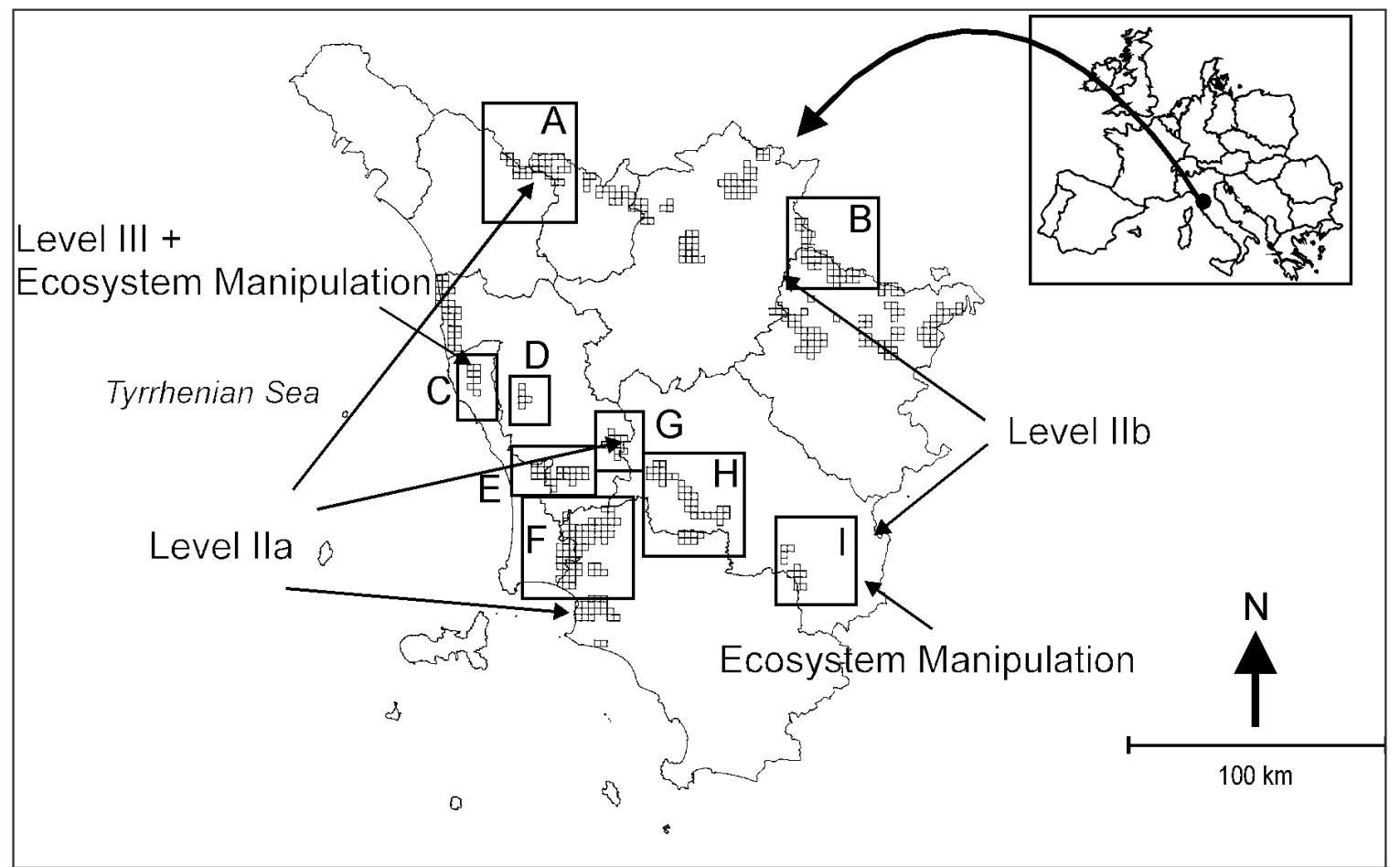

Fig. 1. The MON.I.TO. system. Level I plots are identified by the small squares framed by the A-I rectangles (see legend of table 1); Level II-III plots are indicated by the arrows.

Tab. 1. Surveys carried out in the context of the forest monitoring system in Tuscany during the period 1987-2001. TFI: Tuscan Forest Inventory.

\begin{tabular}{lccc}
\hline & $1987 / 1994$ & $1995 / 1999$ & $2000 / 2001$ \\
\hline Extensive surveys & + & + & + \\
MONITO I and II- Intensive surveys Level II and III & & + & + \\
MONITO III - TOpMODEL, integrated surveys: & & & + \\
- Diversity in vascular and cryptogam plant, linked to TFI & & & + \\
- C stocks, linked to TFI & & \\
\hline
\end{tabular}

notion of intensive monitoring, into what can now best be defined as "integrated" monitoring. The overall picture of the monitoring system active in Tuscany from 1987 (Level I) and then from 1995 onwards (Level IIIII) is shown in figure 1, while its development over time is illustrated in table 1 . This research was carried out in a collaborative study by the Italian Botanical Society, the Department of Environmental Sciences of the University of Siena, the Department of Plant Biology of the University of Florence and the Florence-based consultancy agency LINNÆA ambiente. Thanks to this activity today the Tuscan Region is one of the few Italian regions possessing up-to-date information on the condition of its forests and on the environmental factors capable of exerting a negative influence on forest ecosystems. The purpose of this paper is to provide a historical overview of the programme, describe the current status and the future prospects of the Tuscan forest ecosystem monitoring system.

\section{HISTORICAL OVERVIEW}

\subsection{Large-scale monitoring of forest condition: Level I}

Initially the monitoring network consisted of more than 400 sample plots distributed throughout the forests belonging to the Region (Clauser et al. 1988; Bussotti et al. $1991 \mathrm{a}, \mathrm{b}$ ). From 1991 the sample was reduced to 110 plots, with more than 2500 trees under observation, concentrating on a group of forests that were considered of special regional interest (Bussotti et al. 1995), listed in table 2 and figure 1 . The condition of the trees in these sample plots is still monitored, although at different time intervals. An example of the results that can be obtained by monitoring tree status is shown in figure 2 . Findings in this figure refer to the period 1987-1997. As can be seen, there appeared to be a trend towards worsening conditions for silver fir, black pine, beech and pubescent oak. In some cases tree condition can be related 
Tab. 2. Level I. Tree sample in the different investigated forests in 1995. A: Montagna Pistoiese; B: Casentino; C: Monti Livornesi; D: Santa Luce; E: Magona; F: Follonica; G: Berignone; H: MerseBelagaio; I: Madonna della Querce.

\begin{tabular}{lcccccccccc}
\hline Species & $\mathrm{A}$ & $\mathrm{B}$ & $\mathrm{C}$ & $\mathrm{D}$ & $\mathrm{E}$ & $\mathrm{F}$ & $\mathrm{G}$ & $\mathrm{H}$ & $\mathrm{I}$ & Total \\
\hline Arbutus unedo & 0 & 0 & 6 & 2 & 4 & 14 & 16 & 3 & 2 & 47 \\
Castanea sativa & 0 & 0 & 0 & 0 & 0 & 0 & 0 & 18 & 15 & 33 \\
Fagus sylvatica & 319 & 123 & 0 & 0 & 0 & 0 & 0 & 0 & 0 & 442 \\
Fraxinus ornus & 0 & 0 & 0 & 0 & 0 & 0 & 1 & 0 & 0 & 1 \\
Ostrya carpinifolia & 21 & 0 & 0 & 0 & 0 & 0 & 3 & 0 & 5 & 29 \\
Quercus cerris & 0 & 86 & 1 & 91 & 18 & 114 & 92 & 76 & 54 & 532 \\
Q. ilex & 0 & 0 & 37 & 14 & 45 & 123 & 103 & 23 & 44 & 389 \\
Q. pubescens & 0 & 23 & 16 & 16 & 6 & 99 & 43 & 7 & 159 & 369 \\
Abies alba & 58 & 124 & 0 & 0 & 0 & 0 & 0 & 0 & 0 & 182 \\
Picea abies & 1 & 0 & 0 & 0 & 0 & 0 & 0 & 0 & 0 & 1 \\
Pinus halepensis & 0 & 0 & 2 & 0 & 5 & 0 & 0 & 0 & 22 & 29 \\
P. nigra & 5 & 184 & 0 & 0 & 0 & 0 & 0 & 0 & 12 & 201 \\
P. pinaster & 0 & 0 & 57 & 9 & 0 & 0 & 3 & 84 & 0 & 153 \\
P. pinea & 0 & 0 & 0 & 0 & 15 & 53 & 2 & 1 & 0 & 71 \\
Pseudotsuga menziesii & 1 & 58 & 0 & 0 & 0 & 0 & 0 & 0 & 0 & 59 \\
\hline
\end{tabular}
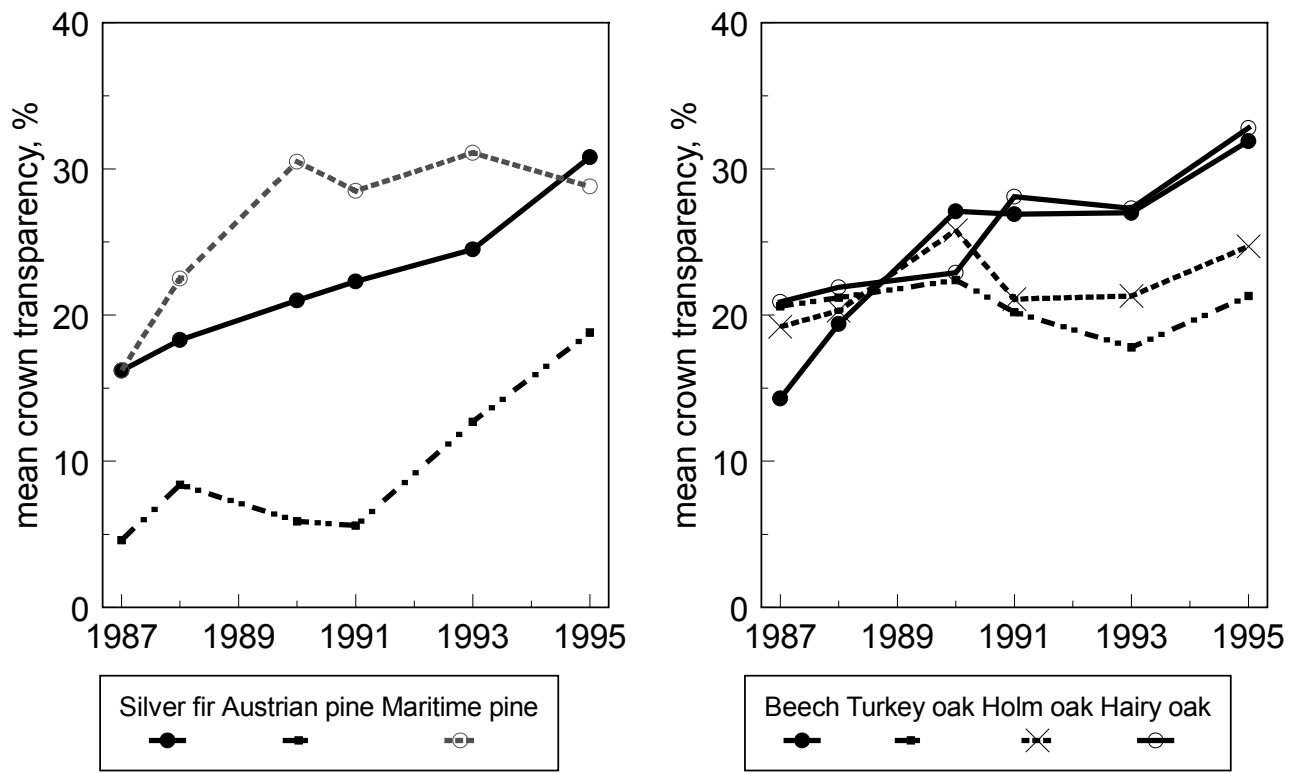

Fig. 2. Evolution of crown transparency over time of 6 main forest species, in the Level I plots network.

to the influence of rainfall, but generally speaking insects are the main recognizable factors causing injury to trees. The Level I network proved to be efficient not only in relation to atmospheric pollution, but was also a useful tool for monitoring the overall health status of regional forests.

Based on the experience provided by this Level I network, the Tuscan Region was able to contribute actively to the development of the pan-European EC UN/ECE programme. In fact, the Tuscan Region hosted the three Intercalibration Training Courses for Mediterranean countries, in 1988 (Florence), 1990 (Volterra) and 1999 (Siena). Experts from Tuscany also contributed to the European Manual for crown assessment of Mediterranean species (Ferretti 1994).

\subsection{Intensive monitoring of forest ecosystems: the Level II network and the MON.I.TO. programme}

In 1995 the Tuscan Region launched the MON.I.TO. programme. The purpose of this programme was to meet two needs: to establish a Level II network within the context of EU - UN/ECE European activities, but without neglecting the historical continuity provided by the findings of the Level I network. Under the MON.I.TO. programme, six permanent plots were established in Tuscany, in three forest types of special ecological interest, as shown in figure 1 and tables 3-4:

- 2 plots in Apennine forests (beech woods), one in Vallombrosa and the other in Foresta del Teso; 
Tab. 3. Site features of the 6 MPM (Monitoring Permanent Plots - Level IIA-B and Level III). More information in Bartolozzi et al. 1996. *: undifferentiated complex. XY coordinates according to Gauss-Boaga projection (national projection derived from UTM projection - datum Roma 40)

\begin{tabular}{|c|c|c|c|c|c|c|}
\hline & $\begin{array}{l}\text { 1. Teso } \\
\text { (PT) }\end{array}$ & $\begin{array}{l}\text { 2. Vallombrosa } \\
\text { (FI) }\end{array}$ & $\begin{array}{l}\text { 3. Colognole } \\
\text { (LI) }\end{array}$ & $\begin{array}{l}\text { 4. Ulignano } \\
\text { (PI) }\end{array}$ & $\begin{array}{l}\text { 5. Madonna d.Q. } \\
\text { (SI) }\end{array}$ & $\begin{array}{l}\text { 6. Bandite di S. } \\
\text { (GR) }\end{array}$ \\
\hline Location & Rombiciaio & Stefanieri & Le Sorgenti & Canestricci & Fontemarchi & Cala Violina \\
\hline Gauss-Boaga X & 1.647 .820 & 1.707 .400 & 1.616 .000 & 1.656 .500 & 1.713 .900 & 1.645 .300 \\
\hline Gauss-Boaga Y & 4.884 .310 & 4.847 .310 & 4.818 .580 & 4.812 .125 & 4.758 .300 & 4.745 .700 \\
\hline Altitude (m asl) & 1350 & 1170 & 250 & 440 & 650 & 5 \\
\hline Aspect & W-NW & $\mathrm{NE}$ & NE & W-NW & N-NW & W-NW \\
\hline Slope $(\%)$ & 17 & 10 & variable & 9 & variable & 5 \\
\hline Bedrock & Sandstone & Sandstone & Clay + Ophiolitic + Lime & Clay & Clay* & Sand \\
\hline Rainfall (mm) & 2090 & 1324 & 978 & 873 & 728 & 637 \\
\hline Mean Temp. $\left({ }^{\circ} \mathrm{C}\right)$ & 9.3 & 10.1 & 15.1 & 12.9 & - & 14.7 \\
\hline Intensity of Monitoring & Level IIa & Level IIb & Level III & Level IIa & Level IIb & Level IIa \\
\hline
\end{tabular}

Tab. 4. Stand features of the 6 PMP. G: basal area; DBH: Diameter at Breast Height. Only trees with diameter $>5 \mathrm{~cm}$ were considered.

\begin{tabular}{lcccc}
\hline PMP & $\begin{array}{c}\text { Stumps } \\
\left(\mathrm{No} \mathrm{ha}^{-1}\right)\end{array}$ & $\begin{array}{c}\mathrm{G} \\
\left(\mathrm{m}^{2} \mathrm{ha}^{-1}\right)\end{array}$ & $\begin{array}{c}\text { mean DBH } \\
(\mathrm{cm})\end{array}$ & Main species \\
\hline Foresta del Teso & 348 & 35.38 & 36 & Beech $(100 \%)$ \\
Vallombrosa & 392 & 50.58 & 40,5 & Beech $(100 \%)$ \\
Colognole & 1545 & 33.92 & 16,7 & Holm oak $(39 \%)$ \\
Cala Violina & 2080 & 31.22 & 13,4 & Holm oak $(69 \%)$ \\
Ulignano & $1536^{*}$ & 17.99 & 12,3 & Turkey oak $(80 \%)$ \\
Amiata & $2061^{*}$ & 29.00 & 13,4 & Turkey oak (76\%) \\
\hline
\end{tabular}

- 2 plots in hilly forest formations in central Tuscany (Turkey oak woods), in the woods at Ulignano (Val di Cecina) and Madonna della Querce (Amiata);

- 2 plots in Mediterranean woods (holm oak woods), at Colognole (Valle Benedetta) and Cala Violina (Bandite di Scarlino).

Beech, Turkey oak and holm oak were chosen because they are representative of the most important forest ecosystems in Tuscany (they cover 63,632 ha, 83,840 ha and 25,536 ha respectively in the region). The plots were chosen so that each pair of permanent plots included two clearly differentiated ecological situations, one more xeric, the other more mesic. The rationale for this was the consideration that, in conditions of widespread pollution, the quantity of deposition depends essentially on the quantity of precipitation.

A wide range of investigations was performed on each plot, following the indications given in European manuals and regulations, but applying an original approach based on scientific research criteria (Tab. 5). The conceptual framework and the structure of MON.I.TO. are clearly illustrated in Bartolozzi et al. (1996). The findings have been published in international scientific journals, in papers such as Ferretti et al. (1999), Loppi et al. (1999), Wilson \& Chiarucci (2000), Chiarucci et al. (2001), Bussotti et al. (2000, 2002a, b). Some examples are reported in figure 3 and tables 6-8. Figure 3 (after Ferretti et al. 1999) shows the behaviour during the study period 1995-97 of some ecological indices related to crown conditions, crown productivity and biodiversity. Table 6 reports the characteristics of the atmospheric depositions in the Level IIb areas. The high contribution of stem-flow in the beech forest is noticeable; this is due to the characteristic branching and bark of beech trees. Finally, tables 7-8 show how carbon and nitrogen may be stored in soil and leaves.

In 1996 the Ministry of Agricultural Policy (MiPA), through its Division V (Corpo Forestale dello Stato), launched the national programme CONECOFOR based on a network of 20 (later 27) Level II plots distributed throughout Italy. The Tuscan Region contributed to the implementation of the CONECOFOR network, first with the plot at Colognole and later with those at Cala Violina and at Vallombrosa.

\section{CURRENT STATUS, TOWARDS INTEGRATED MONITORING MON.I.TO. III - TOPMODEL}

MON.I.TO. III - TOpModel (Tecniche OPerative di MODELlistica spaziale, Operational Techniques of Spatial Modelling) is the evolution of the earlier editions, 1995 - 1997 (I) and 1999 (II), of the MON.I.TO. programme. MON.I.TO. III - TOpModel has inherited from MON.I.TO. I and II the notion of intensive monitoring, an interest in maintaining a monitoring programme on forests and the measuring sites, but it has broadened its range of interest so as to include issues such as environmental change, the greenhouse effect and biodiversity. For these reasons, and in view of the questions that it will address, this third development stage of MON.I.TO. has transformed an intensive programme into an integrated monitoring programme. 
Tab. 5. Actions carried out within the MON.I.TO. programme, objectives and type of measurement

\begin{tabular}{|c|c|c|c|}
\hline Action & Objective & Observation, measurement, analysis & Plots considered \\
\hline Basic site description & Acquisition of basic site data & $\begin{array}{l}\text { Administrative, geographic, topographic and } \\
\text { structural features }\end{array}$ & $\begin{array}{l}\text { Level I } \\
\text { Level IIa, b } \\
\text { Level III }\end{array}$ \\
\hline Advanced site description & Acquisition of detailed site data & $\begin{array}{l}\text { climate, geology, soil, past management, } \\
\text { meteorology, air pollution }\end{array}$ & $\begin{array}{l}\text { Level IIa, b } \\
\text { Level III }\end{array}$ \\
\hline Meteorology (in situ) & $\begin{array}{l}\text { Direct acquisition of } \\
\text { meteorological data to evidence } \\
\text { possible climatic stress }\end{array}$ & $\begin{array}{l}\text { precipitation, wind speed and direction, } \mathrm{T} \text {, } \\
\mathrm{RH} \text {, atmospheric pressure, global radiation, } \\
\text { PAR }\end{array}$ & Level III \\
\hline Flora and vegetation & $\begin{array}{l}\text { Characterisation of the PMP, } \\
\text { analysis of the dynamics }\end{array}$ & species composition and abundance & $\begin{array}{l}\text { Level IIa, b } \\
\text { Level III }\end{array}$ \\
\hline Micology & $\begin{array}{l}\text { Characterisation of the PMP, } \\
\text { analysis of the dynamics }\end{array}$ & species composition & \\
\hline $\begin{array}{l}\text { Biodiversity (vascular plants, } \\
\text { bryophytes, lichens) }\end{array}$ & $\begin{array}{l}\text { Characterisation of the PMP, } \\
\text { analysis of the dynamics }\end{array}$ & species richness, frequencies, dominance & Level III \\
\hline Basic forest features & Characterisation of the PMP & $\begin{array}{l}\text { diameter, social position, freedom of the } \\
\text { crown }\end{array}$ & $\begin{array}{l}\text { Level IIa, b } \\
\text { Level III } \\
\text { Level I } \\
\text { Level IIa, b } \\
\text { Level III }\end{array}$ \\
\hline Advanced forest features & Characterisation of the PMP & $\begin{array}{l}\text { height, depth of the crown, projection of the } \\
\text { crown, horizontal and vertical tree position }\end{array}$ & $\begin{array}{l}\text { Level IIa, b } \\
\text { Level III }\end{array}$ \\
\hline Basic symptomatology & Tree description (20 indices) & crown conditions & $\begin{array}{l}\text { Level I } \\
\text { Level IIa, b } \\
\text { Level III }\end{array}$ \\
\hline $\begin{array}{l}\text { Advanced symptomatology, } \\
\text { phenology }\end{array}$ & $\begin{array}{l}\text { Detailed description of tree } \\
\text { conditions ( } 60 \text { indices })\end{array}$ & $\begin{array}{l}\text { condition of the crown, foliage, branches, and } \\
\text { trunk during the different phenological phases }\end{array}$ & $\begin{array}{l}\text { Level IIa, b } \\
\text { Level III }\end{array}$ \\
\hline Microscopy & $\begin{array}{l}\text { Evaluation of the condition of } \\
\text { the leaves }\end{array}$ & leaf anatomy and ultrastructure & $\begin{array}{l}\text { Level IIb } \\
\text { Level III }\end{array}$ \\
\hline Ecophysiology & Evaluation of water stress & $\begin{array}{l}\text { water potential, stomatal conductance, leaf } \\
\text { fluorescence }\end{array}$ & Level IIb Level III \\
\hline Litterfall & $\begin{array}{l}\text { Evaluation of crown } \\
\text { productivity }\end{array}$ & $\begin{array}{l}\text { dry weight of the abscissed leaves, branchlets, } \\
\text { flowers and fruits }\end{array}$ & $\begin{array}{l}\text { Level IIb } \\
\text { Level III }\end{array}$ \\
\hline Litterfall chemistry & Evaluation of nutrient cycling & $\mathrm{N}, \mathrm{P}, \mathrm{S}, \mathrm{Ca}, \mathrm{Mg}, \mathrm{K}, \mathrm{Na}, \mathrm{Fe}, \mathrm{Mn}, \mathrm{Cu}, \mathrm{Al}, \mathrm{Pb}, \mathrm{B}$ & \\
\hline LAI & $\begin{array}{l}\text { Indirect evaluation of crown } \\
\text { productivity }\end{array}$ & Leaf Area Index & $\begin{array}{l}\text { Level III } \\
\text { Level IIa,b } \\
\text { Level III }\end{array}$ \\
\hline $\begin{array}{l}\text { Foliar biometry, chemistry and } \\
\text { symptoms }\end{array}$ & $\begin{array}{l}\text { Characterisation of the } \\
\text { nutritional status of leaves; leaf } \\
\text { colour; parasites, leaf } \\
\text { morphology }\end{array}$ & $\begin{array}{l}\mathrm{N}, \mathrm{P}, \mathrm{S}, \mathrm{Ca}, \mathrm{Mg}, \mathrm{K}, \mathrm{Na}, \mathrm{Fe}, \mathrm{Mn}, \mathrm{Cu}, \mathrm{Al}, \mathrm{Pb} \\
\mathrm{B} \text {, morphometric parameters }\end{array}$ & $\begin{array}{l}\text { Level IIa, b } \\
\text { Level III }\end{array}$ \\
\hline Soil description & $\begin{array}{l}\text { Characterisation of the PMP, } \\
\text { documentation of possible long- } \\
\text { term variations }\end{array}$ & $\begin{array}{l}\text { kind of soil and humus, description of the soil } \\
\text { layers, colour, structure and texture, roots }\end{array}$ & $\begin{array}{l}\text { Level IIa, b } \\
\text { Level III }\end{array}$ \\
\hline Soil chemistry & $\begin{array}{l}\text { Characterisation of the } \\
\text { nutritional status of the soil }\end{array}$ & $\begin{array}{l}\text { density, } \mathrm{pH} \text {, Corg., } \mathrm{N}, \mathrm{P}, \mathrm{K}, \mathrm{Ca}, \mathrm{Mg} \text {, organic } \\
\text { layer, } \mathrm{CaCO}_{3}\end{array}$ & $\begin{array}{l}\text { Level IIa, b } \\
\text { Level III }\end{array}$ \\
\hline Deposition chemistry & $\begin{array}{l}\text { Determination of exogenous } \\
\text { inputs and their influence on } \\
\text { nutrient cycling }\end{array}$ & $\begin{array}{l}\text { amount, } \mathrm{pH}, \mathrm{K} 20, \mathrm{~N}_{-} \mathrm{NO}_{3}, \mathrm{~N}-{ }_{\mathrm{NH}}, \mathrm{Cl}, \mathrm{SO} 4, \mathrm{P} \\
\mathrm{Ca}, \mathrm{Mg}, \mathrm{K}, \mathrm{Na} \text {. }\end{array}$ & $\begin{array}{l}\text { Level IIb } \\
\text { Level III }\end{array}$ \\
\hline Ozone biomonitoring & $\begin{array}{l}\text { Determination of chronic ozone } \\
\text { exposure }\end{array}$ & $\begin{array}{l}\text { foliar symptoms on Nicotiana tabacum Bel. } \\
\text { W3 and Bel-B }\end{array}$ & $\begin{array}{l}\text { Level IIb } \\
\text { Level III }\end{array}$ \\
\hline
\end{tabular}



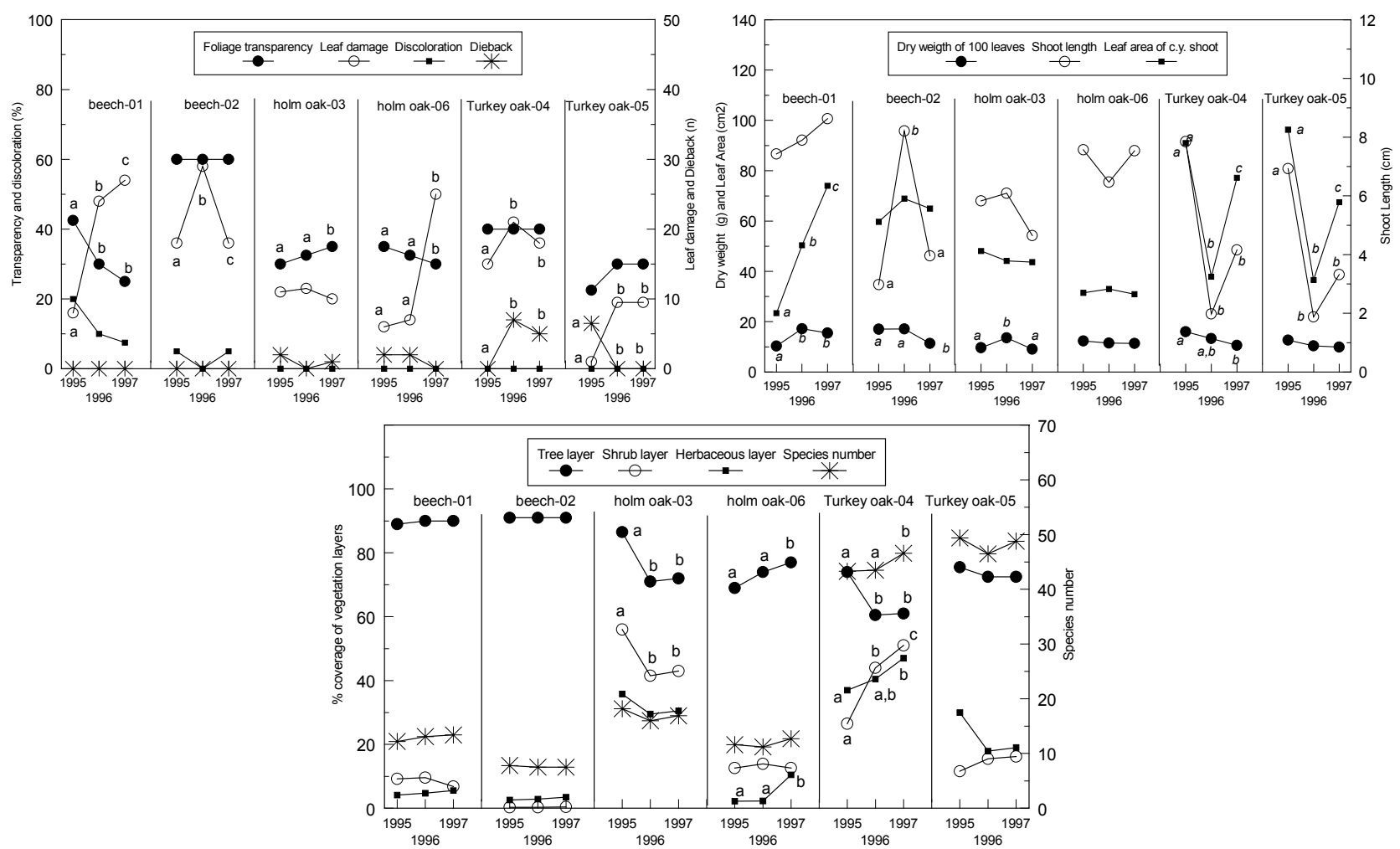

Fig. 3. 1995-1997 trend of different indices of ecosystem status. Upper left: Tree condition. Upper right, crown productivity. Lower, vascular plant diversity. Different letters indicate significant differences $(\mathrm{P}<0.01)$. After Ferretti et al. 1999.

Tab. 6. Deposition $\left(\mathrm{kg} \mathrm{ha}^{-1} \mathrm{y}^{-1}\right)$ of chemical species at Colognole, Amiata and Vallombrosa between January and December 1997. OF $=$ Open Field; TF $=$ Throughfall; SF $=$ Stem flow according the diametric classes expressed in $\mathrm{cm}$.

\begin{tabular}{|c|c|c|c|c|c|c|c|c|c|c|}
\hline Sample & Valid n & $\mathrm{H}^{+}$ & $\mathrm{Ca}^{2+}$ & $\mathrm{Mg}^{2+}$ & $\mathrm{Na}^{+}$ & $\mathrm{K}^{+}$ & $\mathrm{N}-\mathrm{NH}_{4}{ }^{+}$ & $\mathrm{N}-\mathrm{NO}_{3}{ }^{-}$ & $\mathrm{S}-\mathrm{SO}_{4}{ }^{2-}$ & $\mathrm{Cl}^{-}$ \\
\hline \multicolumn{11}{|c|}{ Colognole (holm oak) } \\
\hline $\mathrm{OF}$ & 16 & 119.31 & 7.34 & 1.92 & 12.69 & 5.29 & 6.27 & 2.97 & 7.21 & 26.11 \\
\hline TF & 16 & 11.58 & 10.89 & 8.68 & 20.13 & 24.86 & 8.05 & 4.18 & 13.71 & 40.36 \\
\hline $\mathrm{SF}<10$ & 9 & 0.82 & 0.82 & 0.60 & 0.84 & 1.59 & 0.53 & 0.11 & 0.93 & 2.19 \\
\hline SF $10-20$ & 13 & 1.10 & 0.96 & 0.89 & 1.56 & 2.73 & 0.39 & 0.42 & 1.40 & 3.46 \\
\hline SF $20-40$ & 12 & 2.39 & 0.96 & 0.48 & 1.36 & 2.11 & 0.45 & 0.22 & 1.10 & 2.77 \\
\hline $\mathrm{SF}>40$ & 11 & 0.20 & 0.76 & 0.42 & 0.62 & 2.23 & 0.26 & 0.10 & 0.83 & 1.63 \\
\hline $\mathrm{TF}+\mathrm{SF}$ & & 16.09 & 14.39 & 11.07 & 24.50 & 33.51 & 9.67 & 5.04 & 17.97 & 50.40 \\
\hline \multicolumn{11}{|c|}{ Amiata (Turkey oak) } \\
\hline $\mathrm{OF}$ & 21 & 8.91 & 6.90 & 0.97 & 8.40 & 2.76 & 5.24 & 1.58 & 4.18 & 13.96 \\
\hline $\mathrm{TF}$ & 21 & 7.80 & 8.40 & 2.41 & 11.69 & 13.24 & 8.10 & 2.79 & 5.50 & 23.69 \\
\hline $\mathrm{SF}<12.5$ & 20 & 3.20 & 1.31 & 0.47 & 3.42 & 8.34 & 0.94 & 0.71 & 1.45 & 6.73 \\
\hline SF $12.5-17.5$ & 20 & 18.10 & 3.62 & 1.40 & 8.43 & 13.09 & 2.35 & 2.31 & 3.15 & 17.79 \\
\hline SF $17.5-22.5$ & 20 & 12.90 & 0.84 & 0.28 & 1.56 & 3.05 & 0.63 & 0.52 & 0.81 & 3.24 \\
\hline SF $22.5-27.5$ & 20 & 1.63 & 0.41 & 0.19 & 1.41 & 3.43 & 0.51 & 0.15 & 0.71 & 3.11 \\
\hline $\mathrm{TF}+\mathrm{SF}$ & & 43.62 & 14.58 & 4.75 & 26.50 & 41.15 & 12.53 & 6.49 & 11.62 & 54.56 \\
\hline \multicolumn{11}{|c|}{ Vallombrosa (beech) } \\
\hline OF & 30 & 60.79 & 8.06 & 1.83 & 10.17 & 6.73 & 12.18 & 2.85 & 7.24 & 22.26 \\
\hline $\mathrm{TF}$ & 31 & 84.30 & 12.67 & 3.97 & 19.97 & 14.22 & 10.91 & 5.41 & 9.71 & 43.19 \\
\hline $\mathrm{SF}<40$ & 29 & 16.93 & 1.90 & 0.59 & 3.65 & 4.04 & 1.06 & 0.61 & 2.29 & 7.12 \\
\hline $\mathrm{SF}>40$ & 29 & 7.29 & 0.76 & 0.27 & 1.50 & 2.48 & 0.46 & 0.20 & 1.13 & 3.13 \\
\hline $\mathrm{TF}+\mathrm{SF}$ & & 108.51 & 15.33 & 4.84 & 25.13 & 20.74 & 12.43 & 6.22 & 13.13 & 53.45 \\
\hline
\end{tabular}


Tab. 7. Organic carbon concentration in the mineral soil layers in the MON.I.TO. PMPs. 01: Teso; 02: Vallombrosa; 03: Colognole; 04: Ulignano;05: Amiata; 06: Cala Violina (data expressed as $\mathrm{mg} \mathrm{kg}^{-1}$ )

\begin{tabular}{lcccccc}
\hline Horizon & $\begin{array}{c}\text { PMP 1 } \\
\text { beech }\end{array}$ & $\begin{array}{c}\text { PMP 2 } \\
\text { beech }\end{array}$ & $\begin{array}{c}\text { PMP 3 } \\
\text { Holm oak }\end{array}$ & $\begin{array}{c}\text { PMP 6 } \\
\text { Holm oak }\end{array}$ & $\begin{array}{c}\text { PMP4 } \\
\text { T. oak }\end{array}$ & $\begin{array}{c}\text { PMP 5 } \\
\text { T. oak }\end{array}$ \\
\hline $0-5 \mathrm{~cm}$ & 0.58 & 0.90 & 0.36 & 0.41 & 1.19 & 0.90 \\
$5-10 \mathrm{~cm}$ & 0.33 & 0.30 & 0.20 & 0.17 & 0.25 & 0.22 \\
$10-20 \mathrm{~cm}$ & 0.30 & 0.21 & 0.17 & 0.14 & 0.13 & 0.15 \\
$20-40 \mathrm{~cm}$ & 0.25 & 0.10 & 0.12 & 0.11 & 0.13 & 0.12 \\
$40-80 \mathrm{~cm}$ & 0.15 & 0.14 & 0.12 & 0.10 & 0.09 & 0.08 \\
\hline
\end{tabular}

Tab. 8. Foliar concentration of nitrogen in the sampling period (mean \pm s.d.). PMPs 1: Teso; 2: Vallombrosa; 3: Colognole; 4: Ulignano; 5: Amiata; 6: Cala Violina. Data are expressed as \% of dry weight.

\begin{tabular}{lccc}
\hline PMP & 1995 & 1996 & 1997 \\
\hline 1. Beech & $2.00 \pm 0.24$ & $2.31 \pm 0.16$ & $2.72 \pm 0.28$ \\
2. Beech & $1.86 \pm 0.08$ & $2.04 \pm 0.17$ & $2.55 \pm 0.25$ \\
3. Holm oak & $1.23 \pm 0.05$ & $1.39 \pm 0.06$ & $1.32 \pm 0.08$ \\
6. Holm oak & $1.45 \pm 0.11$ & $1.46 \pm 0.12$ & $1.30 \pm 0.05$ \\
4. Turkey oak & $1.83 \pm 0.13$ & $1.92 \pm 0.16$ & $2.27 \pm 0.20$ \\
5. Turkey oak & $1.83 \pm 0.12$ & $2.10 \pm 0.24$ & $2.13 \pm 0.18$ \\
\hline
\end{tabular}

The aims of the new programme are: (i) to maintain the existing monitoring system of Tuscan forests by continuing activities in Level I and II plots; (ii) to provide a quantitative estimate of levels of carbon stocks in the above-ground biomass and (iii) to achieve a quantitative estimate of plant species diversity in Tuscan forests. In order to do this, the programme must bridge the traditional gap between forest inventories and monitoring activities, using the findings of both in an integrated manner. MON.I.TO. III TOpModel is thus made up of three modules: (b) biodiversity, (c) carbon and (s) status. This last module is no more than the continuation of the earlier MON.I.TO. I and II programmes.

\section{THE WAY FORWARD}

Over the years MON.I.TO. has established itself as one of the most complete regional monitoring programmes. The MON.I.TO. plots have provided data not only for CONECOFOR, but are also part of other international networks, such as UN/ECE ICP on Integrated Monitoring of Air Pollution Effects on Ecosystems and Global Terrestrial Observing System (GTOS) - Terrestrial Ecosystem Monitoring Sites (TEMS). Forest condition monitoring is furthermore considered an element of central importance in the SFM process (Sustainable Forest Management - Helsinki process), in that it not only provides data for the indices envisaged in Criterion 2 (Maintaining health and viability of forest ecosystems), but can also usefully contribute data to Criterion 1 (Maintaining and improving forest resources and their contribution to the global carbon cycle) and Criterion 4 (Maintaining, preserving and improving biological diversity in forest ecosystems).
Thus, based on past experience and in harmony with the philosophy of the TopModel pilot project, the future development of the MON.I.TO. programme will be based on the key words Atmospheric Pollution - Carbon Cycle - Biodiversity - Sustainable Forest Management. This involves improving links and collaboration with the Tuscan Forest Inventory (TFI) and other regional environmental information programmes (metereology, air quality, pest infestations) so as to establish an integrated terrestrial system capable of providing information which can be used to develop scientifically-sound forest and territorial planning programmes.

\section{CONCLUSIONS}

Originally designed to provide baseline data on tree condition through large-scale surveys, the monitoring of forest ecosystems in Tuscany has evolved into a more complex system, in which different compartments and a wide range of chemical, biological and physical properties are assessed. Fundamental to the success of the programme is the fruitful cooperation between the project partners and the local resource managers, as well as the national and international organizations coordinating the relevant monitoring activity. The programme has allowed an identification of baseline conditions and deviations from them, thus providing qualitative and quantitative information on the major threats to forests in Tuscany. As well as continuing in its current activity, the new evolution of the programme will take into consideration further issues of concern, such as sustainable forest management, biodiversity and carbon stocks. This will make the programme fully up-to-date and in line with international political and environmental concerns. 


\section{ACKNOWLEDGMENTS}

This research was financed by Regione Toscana (Project "Studies on Forest Damage", 92.60.IT.009.0 co-financed by the Commission of the European Communities, EC Regulations 3528/86 and 2157/92), Program MON.I.TO. (Intensive Monitoring of Forest in Tuscany), Pubb. no. 21.

\section{REFERENCES}

Bartolozzi, L., F. Bussotti, V. De Dominicis \& M. Ferretti (Eds). 1996. Program MONITO. Concepts, Structure and 1995 Results. Regione Toscana-Giunta regionale Publisher, Firenze: $92 \mathrm{pp}$.

Bussotti, F., E. Cenni, M. Ferretti, L. Brogi \& A. Mecci. 1991a. Danni forestali nei boschi della Toscana: Rapporto 1990. Parte prima: Risultati complessivi e suddivisi per aree omogenee; confronto con le indagini precedenti. Linea Ecologica, 2 (XXIII): 31-36.

Bussotti, F., E. Cenni, M. Ferretti, L. Brogi \& A. Mecci. 1991b. Danni forestali nei boschi della Toscana: Rapporto 1990. Parte seconda: sintomatologia e comportamento di singole specie. Linea Ecologica, 3 (XXIII): 42-46.

Bussotti F., E. Cenni, M. Ferretti, A. Cozzi, L. Brogi \& A. Mecci. 1995. Forest condition in Tuscany (Central Italy). Field surveys 1987-1991. Forestry, 68 (1): 11-24.

Bussotti, F., F. Borghini, C. Celesti \& C. Leonzio. 2000. Leaf morphology and macronutrients in broadleaved trees in central Italy. Trees, 14: 361-368.
Bussotti, F., D. Bettini, P. Grossoni, S. Mansuino, R. Nibbi, C. Soda \& C. Tani. 2002a. Structural and functional traits of Quercus ilex in response to water availability. Environmental and Experimental Botany, 47: 11-23.

Bussotti, F., F., Borghini, C., Celesti, C., Leonzio, A., Cozzi, M., Ferretti \& D., Bettini. (2002b). Leaf shedding, crown condition and element return in two mixed holm oak forests in Tuscany, Central Italy. Forest Ecology and Management: (in press).

Chiarucci, A., V. De Dominicis \& J.B. Wilson. 2001. Structure and floristic diversity in permanent monitoring plots in forest ecosystems of Tuscany. Forest Ecology and Management, 141: 201-210.

Clauser, F., A. Bottacci, L. Brogi, F. Bussotti, E. Cenni, M. Ferretti, R. Gellini, P. Grossoni \& S. Schiff. 1988. Danni forestali di nuovo tipo. Inventario sul Demanio regionale della Toscana e su foreste di particolare interesse regionale. Quaderni di Toscana Notizie, 3: pp.51.

Ferretti, M. (Ed.) 1994. Mediterranean Forest Trees. A Guide For Crown Assessment. CEC - UN/ECE, Brussels, Geneva.

Ferretti, M., I. Bonini, F. Bussotti, C. Celesti, E. Cenni, A. Chiarucci, A. Cozzi, V. De Domincis, P. Grossoni \& C. Leonzio. 1999. Short-term changes of response indicators of ecosystem status in broadleaved forests in Tuscany (Central Italy).Water Air Soil Pollution, 116: 351-356.

Loppi, S., I. Bonini \& V. De Dominicis. 1999. Epiphytic lichens and bryophytes of forest ecosystems in Tuscany (central Italy). Cryptogamie Mycol., 20 (2): 127-135.

Wilson, J.B. \& A. Chiarucci. 2000. Do plant communities exist? Evidence from scaling-up local species-area relations to the regional level. Journal of Vegetation Science, 11: 773-775. 